\title{
Az etnikailag heterogén családok nyelvi szocializációja a tannyelvválasztás tekintetében
}

\author{
Karmacsi Zoltán \\ II. Rákóczi Ferenc Kárpátaljai Magyar Főiskola, Filológiai Tanszék
}

\begin{abstract}
A munkám célja rávilágítani a családokban lezajló nyelvi szocializációs folyamatokra, az azokat irányító, azokat befolyásoló tényezőkre, illetve magára a család (szülők) (nyelvi) szocializációs „terveire” a tannyelvválasztás tekintetében. A vizsgálatban 25 olyan kárpátaljai család vett részt, amelynek egyik tagja magyar, illetve másik tagja ukrán vagy orosz nemzetiségünek és/vagy anyanyelvünek vallotta magát, illetve a gyermek már betöltötte a 3. életévét, de még nem töltötte be a hatodik életévét. A vizsgálatban résztvevő családoknál a látogatás során irányított beszélgetést végeztem a gyerekekkel, ahol a kiindulási alap egy-egy mese, a gyermek hétköznapi tevékenysége, az óvodához és a játékhoz kapcsolódó élményei, a barátokkal és gyerektársakkal élmények, tevékenységek stb. voltak. A szülőkkel kérdőívet töltettem ki, amely alapját a családban zajló nyelvi kommunikáció, a szülők nyelvi háttere és nyelvismerete, identitása alkotta.
\end{abstract}

Kulcsszavak: Kárpátalja, másodlagos nyelvi szocializáció, magyar-szláv etnikailag vegyes házasság, kétnyelvü gyermek

A családban lezajló nyelvi szocializáció fontos aspektusa vagy aspektusai az óvoda ${ }^{1}$ és az iskola tannyelvének kiválasztása, amely a családi (elsődleges) nyelvi szocializáció kiterjedése az intézményi/intézményesített (másodlagos) nyelvi szocializációban. Ez nemcsak nyelvi alapon, hanem kulturálisan és identitásában is meghatározza a gyermek kialakuló világképét, értékítéletét.

Az óvoda és az iskola a tannyelv-választás mellett fontos színtere a kortársakkal történő kommunikációnak. A kortárscsoport a felnőtt-gyermek kapcsolaton túl a legfontosabb nyelvi szocializációs szintér, amely fontos szerepet játszik a különböző beszédmódok elsajátításában és begyakorlásában (Ervin-Tripp \& Mitchell-Kerman, 1977). A gyerekek kortársakkal történő kommunikációban sajátítják el a hasonló korú partnerrel való kommunikációt, a verbális agresszió megnyilvánulásait, a versengés szabályait, a másik beszédének kiigazítását stb. (Réger, 2002). Radó (1996) rámutat, hogy a kétnyelvű közösségekben meghatározó a kortárscsoport domináns nyelve, amely erősítheti vagy gyengítheti valamelyik nyelvet, jelzi a kétnyelvüség stabilitását, az esetleges nyelvcserefolyamatok irányát. Ebből kiindulva, a kisebbségi gyerekek többségi oktatási-nevelési intézménybe történő beíratásakor nagy valószínűséggel olyan kortárscsoportba kerül, ahol a domináns nyelv a többségi, így a már fent említett kortársakkal történő kommunikációban elsajátítható beszédmódok, beszédhatások többnyire többségi nyelven érik majd. Bálint (2005) kutatásai alapján kijelenti, hogy a kölcsönösségen alapuló kapcsolatok meghatározóak a beszélő csoportidentitása szempontjából, s ezáltal befolyása van a nyelvi viselkedésre is. Vagyis ha a kortárs-

\footnotetext{
${ }^{1}$ Az óvodai nevelést én a korcsoportos besorolás szerint az elsődleges nyelvi szocializáció kategóriájába sorolom annak ellenére, hogy ez intézményesített, s ennek hatására valamelyest irányított nyelvelsajátítási folyamatot takar.
} 
csoportban normatívvá válik a vegyes kód használata, akkor az megjelenik a más beszélőkkel való kapcsolatban is. A gyermek a szerepek próbálgatásával a kortárscsoportban megtapasztalja a kisebbségi létből, a kétnyelvüségből adódó másságot, s ez a kapcsolatrendszer az itt kialakuló nyelvi szokások és nyelvi viselkedés révén viszszahat a családon belüli nyelvhasználatra, többek között a testvérekkel való kommunikációban nyilvánul meg. A Felvidéken (Szlovákia) végzett ${ }^{2}$ kutatásom során ehhez hasonló viselkedést tapasztaltam a garamkövesdi (szlovákul Kamenica nad Hronom) Vikicánál, aki a szülők elmondása szerint az óvodába lépés előtt a szülők anyanyelvén szólt hozzájuk, azonban a többségi nyelvű óvoda hatására a magyar anyanyelvü apjához is csak szlovákul volt hajlandó szólni:

\section{Vikica 2010 Garamkövesd $(3 ; 5)$}

APA: Gyere, mondd el, mit látsz itt! Megmutatod nekem?

AK: Nie. [Nem.]

APA: Nem? És miért nem? Legózni akarsz?

AK: Áno ja sama. [Igen én magam.]

APA: Egyedül?

AK: Áno. [lgen.]

TM1: És mit építesz?

APA: No Viki mondd el, mit építesz!

AK: Viki sa vel'mi vel'mi hnevá. [Vikike nagyon nagyon haragszik.]

MATKA: A prečo Vikinka, čo sa deje? [Miért,Vikike mi történik?]

AK: Vikinka je vel'mi vel'mi zlá. [Vikike nagyon nagyon rossz.]

\section{A kutatási terület és a kutatópontok rövid bemutatása}

A családok kiválasztásánál elsősorban a kisebbség területi létszámarányának szempontját tartottam fontosnak, vagyis azt, hogy milyen az arány a többségi és kisebbségi lakosok között az adott régióban. Ez alapján két csoportot alakítottam ki: a szórványban élő magyarok csoportját, amelybe a Munkácsi, Huszti, Técsői, Rahói járások, illetve Munkács, Ungvár, Huszt városok kerültek; továbbá a tömbben élő magyarság csoportját, amelybe az Ungvári, Nagyszőlősi és Beregszászi járások, illetve Beregszász és Csap városok kerültek ${ }^{3}$.

Aszórványban élő magyarok csoportjánál 9 családban (Munkácson 5, Beregrákoson 1 és Visken 3) és a tömbben élő magyarok csoportjánál 16 családban (Beregszászon 5, Orosziban 3, Macsolán 3, Kovászón 2, Fancsikán 1, Oroszvölgyön 2) végeztük el a vizsgálatot (vö. 1. táblázat).

\begin{tabular}{|l|c|c|c|}
\hline \multirow{2}{*}{ település } & \multirow{2}{*}{ lakossága } & \multicolumn{2}{|c|}{ ebböl magyar } \\
\cline { 3 - 4 } & & fő & $\%$ \\
\hline Munkács & 81637 & 6975 & 8,5 \\
\hline Beregszász & 26050 & 12779 & 49,1 \\
\hline Oroszvölgy & 442 & 48 & 10,9 \\
\hline Visk & 8142 & 3699 & 45,4 \\
\hline Macsola & 675 & 545 & 80,7 \\
\hline
\end{tabular}

\footnotetext{
2 2014-ben Nyitra és Párkány környékén 8 etnikailag vegyes (szlovák-magyar) családban végeztem felmérést a kárpátaljai vizsgálat módszerét felhasználva. A kutatás a V4EaP Scholarship Program támogatásával készült.

${ }^{3}$ A felosztás alapjául az ukrajnai 2001-es népszámlálási adatbázist vettem (Molnár és Molnár, 2005).
} 


\begin{tabular}{|l|c|c|c|}
\hline Fancsika & 2059 & 770 & 37,4 \\
\hline Oroszi & 895 & 852 & 95,2 \\
\hline Beregrákos & 3280 & 1493 & 45,5 \\
\hline Kovászó & 899 & 49 & 5,5 \\
\hline
\end{tabular}

1. táblázat: A kutatópontok lakosságának száma, ezen belül a magyarság száma és aránya

(Molnár és Molnár, 2005. 82-85. o. alapján)

\section{A vizsgálat menete és módszerei}

A vizsgálatban 25 olyan kárpátaljai család vett részt, amelynek egyik tagja magyar, másik tagja ukrán vagy orosz nemzetiségűnek és/vagy anyanyelvűnek vallotta magát, illetve a gyermek már betöltötte a 3 . életévét, de még nem töltötte be a hatodik életévét, vagy nem tanult meg olvasni4 (lásd 2. táblázat). A családoknál a látogatás során irányított beszélgetést végeztem a gyerekekkel, ahol a kiindulási alap egy-egy mese, a gyermek hétköznapi tevékenysége, az óvodához és a játékhoz kapcsolódó élményei, a barátokkal és gyerektársakkal élmények, tevékenységek stb. voltak. A szülőkkel kérdőívet töltettem ki, amelyben többek között a család aktuális nyelvi szocializációs környezetére, a nyelvek ismeretére, a családban a többségi és kisebbségi nyelvek használatának mind a szülök, mind pedig a szülö(k) és gyermek(ek) közötti aránybeli megoszlására stb. rákérdeztem. A kitöltés közben a szülőkkel a család tágabb szociális életteréről beszélgettem.

\section{Az óvoda tannyelvének kiválasztása}

Az első családon kívüli intézményesített nyelvhasználati színtér az óvoda, mely esetében gyermekük számára a kárpátaljai vizsgálatban részt vett szülők többsége (15 gyerek) a kisebbségi tannyelvű intézményt választotta, míg 10 gyerek ukrán tannyelvű óvodába, egy oroszvölgyi (ukránul Ruszka Dolina) gyermek ukrán tannyelvű óvodába jár, ahol azonban magyar nyelven is folynak foglalkozások. Az adott óvoda kiválasztásánál döntésüket a szülők sok esetben hétköznapi dolgokkal indokolták, mint például az alábbi szülői válaszokból is láthatjuk:

„тому що в селі є тільки один садок з угорською мовою” [mert a községben csak magyar nyelvü müködik] (Artúr 2005, Oroszi, nő, ukrán/magyar)

„Mert közelebb van az otthonunkhoz” (Stefike 2006, Macsola, férfi, magyar és ukrán/magyar)

Persze ettől vannak tudatosabb nyelvi elképzeléssel felvértezett szülők, akik már az óvoda esetében is a gyermek számára nyelvi szempontból is a „legcélravezetőbbet”, a „leghasznosabbat” szeretnék kiválasztani:

„Azért, hogy tudjon ukránul” (Alex 2003, Kovászó, nő, magyar/ magyar)

\footnotetext{
${ }^{4}$ Ezért azok a gyermekek is belekerülhettek a vizsgálatba, akik 6. életévük betöltése előtt már iskolába jártak és akik ugyan szeptemberben elkezdték az iskolát, de még nem sajátították el az olvasást, vagyis az iskola első osztályának első félévében jártak.
} 
(ukrán nyelvübe) „Hogy boldoguljon, mert én magyar iskolába jártam és nehéz volt." (Annamária 2003, Beregszász, nő, magyar/magyar)

(magyar nyelvübe) „Hogy anyanyelvükön beszéljenek és tanuljanak." (Zsoltika 2004 és Marica 2003, Beregszász, nő, magyar és ukrán/magyar és ukrán)

Összefoglalva az óvodai nevelés tekintetében elmondható, hogy a legtöbb család számára, különösen a kisebb települések esetében, nincs lehetőség az óvoda tannyelvének kiválasztásában, hiszen a településen csak egy iskola előtti nevelési intézmény müködik. A vizsgálatban nyolc család jelölte meg ezt a válaszlehetőséget indokként. További két család az óvodák közelségével indokolta a választást. Az óvodai tannyelvválasztásnál csak hat család említi a jobb boldogulás, az államnyelv elsajátítása és az Ukrajnában élünk okokat. Ugyanennyi családban látják úgy, hogy a magyar nyelvű nevelési intézmény a gyermek kisebbségi anyanyelvének fejlesztésében, a magyar nyelv megörzésében stb. lehet a gyermek hasznára.

\section{A másodlagos nyelvi szocializáció jellemzői}

A gyermek nyelvi szocializációját, fejlődését jelentős mértékben befolyásolja az iskola tannyelvének kiválasztása. Sorbán szerint a többségi tannyelvű iskola „a kisebbségi kulturális viszony rendszerből való kilépés első lépcsőfoka" (Sorbán, 2000. 169. o.). A gyermek és a fiatal nyelvi szocializációjában az iskoláskor fontos szerepet tölt be, hiszen ekkor alakulnak ki az anyanyelvnek azok a regiszterei, amelyeket nem spontán módon sajátítunk el másoktól, hanem az iskolában tanulunk az alapmüveltség megszerzése közben (Szilágyi N., 2004).

Az óvodai nevelés után 11 családban a szülök úgy gondolják, hogy gyermeküket többségi tannyelvű iskolába fogják beíratni. Ide sorolhatók azok a gyermekek is, akiknél az egyik szülő még bizonytalan az iskola tannyelvével kapcsolatban, de a másik szülő az ukránt jelölte meg (1 család), s azok a családok is, ahol az egyik szülö adott csak választ a kérdésre ( 2 család), illetve az a család is, ahol a választás az ukrán és az orosz tannyelv között dől majd el. Vagyis összességében 13 gyermek kezdheti meg majd tanulmányait többségi tannyelvű iskolában, melyek közül 7 gyermek kisebbségi tannyelvű óvodába járt (vö. 2. táblázat).

\begin{tabular}{|l|l|l|}
\hline \multicolumn{1}{|c|}{ Gyerek } & \multicolumn{1}{c|}{ Óvoda tannyelve } & \multicolumn{1}{c|}{ Iskola tannyelve } \\
\hline Regina 2003, Oroszi & magyar & ukrán \\
\hline Alex 2003, Kovászó & ukrán & ukrán \\
\hline Krisztina 2003, Oroszi & magyar & még nem döntöttek \\
\hline Artúr 2005, Oroszi & magyar & ukrán \\
\hline Máté 2005, Macsola & magyar & ukrán \\
\hline Annamária 2003, Beregszász & ukrán & ukrán \\
\hline Danika 2003, Munkács & magyar & még nem döntöttek \\
\hline $\begin{array}{l}\text { Zsoltika 2004, Marica 2003† } \\
\text { Beregszász }\end{array}$ & magyar & magyar \\
\hline Stefánia 2006, Beregszász & magyar & ukrán \\
\hline Martin 2006, Macsola & magyar & magyar \\
\hline Sanyika 2003, Beregszász & ukrán & ukrán \\
\hline
\end{tabular}




\begin{tabular}{|l|l|l|}
\hline Angelina 2007, Visk & ukrán & magyar/még nem döntött \\
\hline Adrián 2006, Visk & ukrán & nem válaszoltak \\
\hline Lajcsika 2007, Visk & ukrán & ukrán/magyar \\
\hline Tányka 2004, Fancsika & magyar & ukrán \\
\hline Márjánocska 2004, Oroszvölgy & magyar és ukrán & még nem döntöttek \\
\hline Dani 2002, Munkács & ukrán & orosz/ukrán vagy orosz \\
\hline Viktorka 2004, Munkács & magyar & magyar \\
\hline Dórika 2002, Munkács & ukrán, majd magyar & magyar \\
\hline Valika 2004, Beregrákos & ukrán & magyar \\
\hline Dánocska 2005, Munkács & magyar & ukrán \\
\hline István 2006, Kovászó & ukrán & ukrán \\
\hline Karina 2006, Macsola & magyar & magyar \\
\hline Daniella 2004, Beregszász & ukrán & ukrán \\
\hline Janocsko 2005, Oroszvölgy & magyar & ukrán \\
\hline
\end{tabular}

2. táblázat: A gyermek számára választott oktatási intézmények a tannyelv szerint

A szülők 6 gyermek esetében a magyar tannyelvű iskolát választják majd. Azonban az egyik családban az egyik szülő bizonytalan még, de a másik szülő egyértelmüen a magyar tannyelvű iskolát jelölte meg. Vagyis a magyar tannyelvű beiskolázást 7 családban jelölték meg. Négy családban a szülök még nem döntöttek az iskola tannyelvét illetően, továbbá egy családban egyik szülő sem adott választ a kérdésre (vö. 2. táblázat).

Érdekes, hogy egy viski és egy beregrákosi család ukrán tannyelvű óvoda után adja magyar tannyelvű iskolába a gyermekét. S hogy miért?

„Azért, mert ott dolgozom, s így könnyebb lesz mindkettőnknek” (Angelina 2007, Visk, nő, magyar/magyar)

„Hogy jól tanuljanak meg írni és olvasni, és a magyar történelmet" (Valika 2006, Beregrákos, férfi, magyar/magyar)

„Пусть знають все мови” [Hadd tudják mindegyik nyelvet.] (Valika 2006, Beregrákos, nő, ukrán/ukrán)

Az iskola tannyelvének kiválasztásánál elötérbe kerülnek a többségi állam rejtett oktatási, nyelvpolitikai céljai, amelyek a kisebbségi lakosok számára az anyanyelvükön való továbbtanulást értéktelennek, zsákutcának tüntetik fel. A vizsgálatban részt vevő családok közül 7 család indokolta gyermeke ukrán tannyelvű beiskoláztatását azzal, hogy Ukrajnában élünk, ez az államnyelv, hogy jobban boldoguljon az életben. Ebből kiindulva az iskola tannyelvválasztásánál az első számú szempont a másodlagos nyelvi szocializáció folyamatában az oktatási és nyelvpolitikai rejtett célok szülők döntésére gyakorolt hatása.

„Тому, щоживемо в Україні” [Azért, mert Ukrajnában élünk] (Lajcsika 2007, Visk, nő, ukrán/ukrán)

„Nagy hiba volt, hogy én nem ukrán iskolába jártam, mert nehéz volt boldogulni." (Annamária 2003, Beregszász, nő, magyar/ magyar) 
Ez utóbbi példán jól látszik, hogy a szülő a gyermeke másodlagos nyelvi szocializációjába a saját nyelvszocializációs tapasztalatait is beépíti. Hasonló tényeket állapít meg Sorbán (2000. 145. o.) is a romániai magyar kisebbség tannyelvválasztásával kapcsolatban. Szerinte az a tényező, hogy a szülők milyen tannyelvű iskolába jártak, kiemelt szerepet kap saját gyermekük beiskolázásakor a tannyelvválasztásban. A személyes tapasztalat nemcsak a többségi tannyelvű iskolaválasztás esetében kerülhet előtérbe, hanem ugyanúgy a kisebbségi tannyelvű iskolaválasztásánál is, mint ahogy az alábbi szülői indoklásban is megjelenik:

„Én is magyar iskolát végeztem, itt dolgozom, így örizhetjük meg a magyarságunkat." (Viktorka 2004, Munkács, nő, magyar/magyar)

Mint ahogy a fenti példában is a magyar tannyelvű iskolaválasztásnál a kisebbségi lét, a magyar nyelv megőrzése is fontos tényezővé lép elő, úgy az alábbi esetben is ez a nyelvi szocializációs szempont dönt az iskola tannyelvének kiválasztásánál:

(magyar iskolába) „Hogy anyanyelvükön tanuljanak.” (Zsoltika 2004 és Marica 2003, Beregszász, nő, magyar, ukrán/magyar, ukrán)

A beiskolázás indoklásánál kíváncsi voltam arra, hogy a szülök döntésére hatással van-e a szülök végzettsége, a végzettség mutat-e összefüggést a többségi állam rejtett oktatási, nyelvpolitikai céljaként megjelenő szülői indokokkal. A vizsgálatban részt vevő általános iskolai végzettséggel rendelkező szülők közül mindösszesen ketten említették az államnyelv elsajátítása és az ukrán nyelven való könnyebb boldogulás eszményét. Hasonló arányban említették ezen indoklehetőséget a felsőfokú végzettséggel rendelkező szülők is. A szakoktatási intézményt (szakiskolát) végzett szülők (20) azonban jóval többször (8 szülö) indokolták a többségi tannyelvű iskola választásánál döntésüket azzal, hogy ez az államnyelv, csak az ukrán nyelvvel lehet boldogulni, s hogy Ukrajnában élünk. S ha mindehhez hozzávesszük azt, hogy a szülök közül 3-an nem indokolták válaszukat, 1 még nem döntött és 4-en az iskolaválasztás lehetőségének hiánya miatt döntöttek úgy, akkor ez a számarány jelentős arányú az indokok között. Ha viszont a családok szintjén haladunk tovább, akkor láthatjuk, hogy két családban mindkét szülő szakközépiskolai végzettséggel rendelkezik, illetve további három családban a szakközépiskola végzettséggel rendelkező szülő és egyéb végzettséggel rendelkező házastársa is hasonló indokok miatt döntöttek a többségi tannyelvü beiskoláztatás mellett. Mindenképpen megjegyzendő, hogy ugyan az egyik szakközépiskolai végzettséggel rendelkező férj az ukrán tannyelvű beiskoláztatás indokaként úgy fogalmazott, hogy a gyermek „tudja mindkét nyelvet”. Azonban a felesége indoklása, akinek általános iskolai végzettsége van, egyértelmüen az előző indokok mentén körvonalazódik az ukrán tannyelvü beiskoláztatás: „Mivel Ukrajnában élünk, a magyar ajkú embereknek egyre nehezebb, így úgy döntöttünk, hogy ukrán iskolába adjuk a gyermekünket."

Az általános iskolai végzettségüek esetében előfordul, hogy megfontolt stratégia mentén döntenek az iskola tannyelvének kiválasztásánál, mint ahogy az oroszvölgy Márjánocska édesanyja válaszában is láthatjuk:

„Буде видно, на якій краще розмовлятиме. Бо поукраїнськи на даний час розмовляє, а на угорський слабше." [Majd meglátjuk, melyik nyelven beszél jobban. Mert most ukránul beszél, magyarul viszont gyengébben] (Márjánocska 2004, Oroszvölgy, nő, ukrán/ukrán) 
A felsőfokú végzettséggel rendelkező szülők esetében a nem válaszoltak (4 szülö), a még nem döntöttek (1) és a csak ilyen iskola van a települése (2 szülő) mellett konkrét elképzelések is megjelennek az iskola tannyelvének kiválasztásánál. A munkácsi Dórika esetében a felsőfokú végzettséggel rendelkező szülők a magyar nyelv anyanyelvként történő elsajátítását egyértelmüen nyelvszocializációs célként tűzik ki, amelyet az édesanya indoklása jól tükröz:

(magyar iskolába) „Бо у неї батько угорець, вона народилася в Угорщині. Ми б хотіли, щоб угорська була для неї, як рідна мова." [Mert az apja magyar, ő Magyarországon született. Mi azt szeretnénk, ha a magyar lenne az anyanyelve.] (Dórika 2005, Munkács, nő, ukrán/ukrán)

A házastársak közötti kommunikációban a férj föként ukránul beszél feleségéhez, mivel „a feleségem ukrán anyanyelvü”; a feleség szerint a kommunikációban egyforma arányban vesz részt mindkét nyelv. A gyermekkel való kommunikációban az apa többnyire magyarul beszél, míg a feleség közel egyforma arányban használja mindkét nyelvet. Az apa tudatosan a nyelv elsajátításának céljával használja a magyar nyelvet gyermekével, míg az édesanyja csak azért beszél hozzá ukránul, mert nem mindig áll rendelkezésére a megfelelő kifejezés magyarul. A gyermek a szülők nyelvhasználatához igazítva válaszol. A család esetében a magyar nyelv anyanyelvként való elsajátíttatása a gyermekkel ugyan célként van kitűzve, de az anya részéről ennek nyelvi hiányossága van, az apa sem csak a magyar nyelvet alkalmazza gyermekéhez szólva, illetve a házastársak egymás közötti kommunikációjában is a férj szerint többségében ukránul, míg felesége szerint mindkét nyelven zajlik a kommunikáció, amely a gyermek számára nem ad egyértelmű magyar nyelvi mintát. Azonban a családlátogatások során tapasztalt családi, és föként szülő-gyermek közötti kommunikáció nyelvválasztása nem teszi egyértelművé a szülők indoklását, s nem lehet eldönteni egyértelműen, hogy ez csak a vizsgálati helyzethez igazodó „szép szavak”, vagy ténylegesen a család mindennapjaiban jelenlévő cél.

Szintén a magyar identitástudat és a magyar nyelv megőrzését tartják szem előtt a munkácsi Viktorka szülei is. A felsőfokú végzettséggel rendelkező magyar nemzetiségü és anyanyelvű édesanya az iskola tannyelvének kiválasztásakor — a személyes tapasztalatok mentén értékelve - a gyermek magyarságának megőrzését tekinti mérvadónak. A szintén felsőfokú végzettséggel rendelkező ukrán nemzetiségü és anyanyelvű édesapa szerint a magyar nyelv elsajátítása a jövőben a gyermek hasznára válhat.

Az iskola tannyelvének kiválasztásánál már nem tủnik oly mértékben lényeges (csak 3 család válaszolt így) szempontnak az — mint az óvodák esetében -, hogy a településen csak ilyen tannyelvü intézmény müködik. A szülők itt már akár más településekre is hajlandók beiskoláztatni gyermeküket a kívánt tannyelv elérése szempontjából.

Göncz Lajos (2004. 59. o.) szerint a szülők szeretnék, hogy gyermekeik mindkét nyelvben magas szintü jártasságot szerezzenek, de mivel kevés ismeretük van a kétnyelvü gyermekek nyelvi fejlődéséről, abból a naiv elképzelésből indulnak ki, hogy az anyanyelvét már úgyis megtanulta, ezért a többségi nyelvű oktatást választja, hogy a többségi nyelvet is elsajátítsa. Nincs ez másként Kárpátalján sem, hiszen az alábbi családok is hasonlóan vélekednek: 
„Бо якщо дитина після школи, захоче ще навчвтись, то їй більш потрібна буде українська мова. Так як ми проживаємо на України. А угорську завжди будуть знати, так як це їхня рідна мова." [Hogyha gyerek az iskola után tovább akar tanulni, akkor jobban szükséges lesz az ukrán nyelvre. Hiszen Ukrajnában élünk. A magyar nyelvet mint anyanyelvét pedig mindig fogja tudni] (Máté 2005, Macsola, nő, ukrán/ukrán)

„Мабуть в російську. Угорською і українською він володіє добре, а знати івивчати інші мови явважаю, що корисно."[Talán az orosz (tannyelvübe sic!). Magyarul és ukránul jól beszél, de én úgy gondolom, hogy több nyelvet elsajátítani és tudni hasznos.] (Dani 2002, Munkács, nő, ukrán/ukrán)

„Mert jó, ha több nyelvet ismer. A magyart úgyis tudja, mivel édesapja és nagyszülei magyar anyanyelvüek." (Dani 2002, Munkács, férfi, magyar/magyar)

Göncz Lajos (2004. 59. o.) erröl úgy vélekedik, hogy a felcserélő kétnyelvüségi helyzetben ez a stratégia nemhogy magas szintű kétnyelvüséget nem eredményez, de gyakran inkább a többségi nyelv dominanciájához és az anyanyelv elsorvadásához vezet, távlatilag pedig akár nyelvcseréhez is. Az etnikailag vegyes házasságokban e stratégia szintén a kisebbségi nyelv értéktelenné válását, elsorvadását eredményezheti.

A szülők által szívesen alkalmazott másik jellemző beiskoláztatási stratégia, hogy a kisebbségi iskolában való iskolakezdés után átíratják a többségi nyelvű iskolába, hogy megtanulja a többségi nyelvet is. A beregrákosi Valika $(5 ; 8)$ családjában az iskolaválasztás a magyar tannyelvű iskolára esik ugyan, amellyel mindkét szülő egyetért. Azonban a beszélgetés során kiderült, hogy a szülök egyike sem zárja ki a lehetőségét annak, hogy 5 . osztálytól a gyermeket átíratják az ukrán tannyelvű iskolába. Az édesapa szerint ez majd jót tesz a gyermeknek, hiszen ő is hasonlóképpen jutott el az érettségiig, s így lehetösége volt arra, hogy megtanulja mind a magyar, mind pedig az ukrán nyelv grammatikai rendszerét. Az eredmény hasonló lehet az előző bekezdésben Göncz Lajos által felvázolt eredményekhez. Különösen igaz ez azoknál a gyermekeknél, akiknél a többségi nyelv kompetenciája semmi vagy nagyon alacsony.

Kárpátalján a magyar homogén házasságban élő szülők sok esetben a többségi nyelv alapszintü ismerete nélkül is beíratják gyermekeiket a többségi tannyelvü iskolába, s nem veszik figyelembe azt a tényt, amelyet például a munkácsi Dánocska felsőfokú végzettséggel rendelkező szülei figyelembe vesznek az iskola tannyelvének kiválasztásakor. Az ukrán nemzetiségủ és anyanyelvü édesapa csak néhány szó erejéig beszéli a magyar nyelvet, $s$ ezért az ukrán tannyelvű iskola választásánál a magyar nyelv nehézségét adja meg indokul. A magyar nemzetiségü, de orosz anyanyelvű édesanya, aki maga is csak jól beszél magyarul, gyermekét azért szeretné ukrán tannyelvü iskolába íratni, mert „a gyermek nehezen beszél magyar nyelven, súgy hiszem, hogy a magyar tannyelvü iskolában nehézségei lehetnek a tanulásban." $\mathrm{A}$ szülök nem véletlenül alapozzák erre a válaszukat, hiszen mind a házastársak közötti,

\footnotetext{
${ }^{5}$ Az édesanya válaszát eredetileg az itt olvasható ukrán nyelven fogalmazta meg: дитина важко сприйма єугорську мову, вважаю, що в угорський школі виникатимуть більші складності з навчанням.
} 
mind pedig a gyermek és a szülők közötti kommunikációban többségében az ukrán és orosz nyelv használatos. Vagyis ez esetben a szülők a döntést a kisebbségi nyelv nem megfelelő ismeretére alapozva hozzák meg, s terelik a gyermeküket a másodlagos nyelvi szocializációban a többségi nyelv felé, amely mintegy szerves folytatása a szintén javarészt többségi nyelven zajló családi nyelvi szocializációnak.

A szülői tannyelvválasztási döntéseket Séra Magdolna (2010, 171-173. o.) saját kutatásának eredményei alapján tannyelvválasztási motívumokban foglalta össze: 1. rejtett kompenzáció, 2. magyarországi továbbtanulási cél, 3. magyar nyelven való tanulás fontossága, 4. nyelvtudás megszerzése, 5. társadalmi mobilitás (ukrán nyelven fog csak tudni érvényesülni), 6. magas szintű tudás megszerzése.

A vizsgálatban részt vevő etnikailag vegyes családok többségében a szülők szintén e motívumok mentén beazonosítható válaszokkal indokolták meg azon döntésüket, miszerint a kisebbségi vagy többségi tannyelvű iskolát részesítik majd előnyben gyermekük részére. Az etnikailag vegyes családokban is erőteljesen jelen van a társadalmi mobilitás (5 szülö, 4 család $^{6}$ ), mint az iskolai tannyelv-választást befolyásoló tényező. Azonban itt kiemelném azt, mint tannyelvválasztási döntést befolyásoló motivációt, amikor a szülő válaszában az államnyelv (mert ez az államnyelv, 2 szülő, 1 család) vagy az Ukrajnában való élés (mert Ukrajnában élünk, 5 szülő, 4 család) motívumot adta meg indokul. Ugyan valamiféleképpen kapcsolódhat a társadalmi mobilitáshoz, de itt inkább a többségi állam által megfogalmazott kötelesség jelenik meg a kisebbségi lakosok irányában, ami a szülői válaszokban is tükröződik. Vagyis haezt motivációként szeretnénk megfogalmazni, akkor társadalmi kötelességként azonosíthatjuk. Ugyancsak egy új motiváció megjelenése az, amikor a szülők a gyermek nyelvi kompetenciáját (nyelvtudását vagy nyelvtudásának hiányát) adják meg indoknak a tannyelvválasztásban indokként. Ez a gyermek nyelvi kompetenciája mint beiskolázási motiváció. Szintén önálló, eddig nem említett motiváció (s egyben döntési kényszer is) lehet az, amikor csak adott tannyelvű iskola áll rendelkezésre az adott településen (6 szülő, 3 család). Ezt nevezhetjük a nincs más tannyelvű iskola motivációjának. A már korábban Séra Magdolna által meghatározott motivációkból a vizsgálatban még említették a nyelvtudás megszerzését ( 7 szülő, 4 család), a magyar nyelven való tanulás fontosságát (4 szülő) és a rejtett kompenzáció is előkerül egy szülőnél.

Az iskola tannyelvének kiválasztásánál a vizsgálatban a szülők előzetesen beszéltek terveikről. 2015 tavaszán megpróbáltam elérni a kutatásban részt vett családokat, és információt szerezni arról, hogy a gyermekek milyen tannyelvű iskolába járnak. A 25 családból 15-öt sikerült közvetlenül vagy az egykori terepmunkás társaimon keresztül elérnem. A korábbi tervekhez képest 10 család nem tért el, s olyan tannyelvü iskolába adta gyermekét, amilyet a vizsgálat idején megadott. De nem minden családban maradtak a szülők a beiskolázáskor az eredeti tervek mellett. A munkácsi Dánocskánál a szülök mindketten az ukrán tannyelvü iskolát említették, azonban a gyermeket végül magyar tannyelvű iskolába jár. Döntésük megváltoztatását azzal indokolták, hogy nagyobbik lányuk is magyar iskolába jár, és így könnyebb lesz a kicsinek is. Az oroszvölgyi Márjánocska és a viski Adrián esetében a kérdőívben a szülők nem válaszoltak, illetve Márjánocska édesanyja még nem döntött az iskola tannyelvét illetően. Azonban mindkét gyermek esetében a szülők az ukrán tannyelvű iskolát választották. A gyermekkel való nyelvhasználat (többnyire ukránul) és az óvoda tannyel-

6 A szülő száma azt jelöli, hogy hány szülő adta ezt a választ, míg a család száma azt, hogy ezek a szülök hány családban élnek: vagyis esetünkben két szülő ugyanazon családban él. 
ve (ukrán tannyelvű) mintegy előrevetítették a szülők ezen döntését. Továbbá érdemes még megemlíteni a munkácsi Dani esetét is, hiszen a vizsgálat idején az ukrán nemzetiségű és anyanyelvű édesanya egyértelműen az orosz tannyelvet jelölte meg, míg a magyar nemzetiségű és anyanyelvű édesapa az orosz és az ukrán tannyelv között hezitált. A gyermek napjainkban orosz-ukrán vegyes tannyelvü iskola ukrán tannyelvű osztályába jár. A macsolai Karina esetében is a korábban magyar tannyelvü iskolába való beiskolázási tervek után az egyik beregszászi vegyes tannyelvű iskola ukrán tannyelvű osztályába írattak be gyermeküket. Bár korábban azzal indokolták a szülök a magyar tannyelvü iskola melletti döntésüket, hogy csak ilyen iskola található a településükön ${ }^{7}$ és nem szeretnék más településre vinni iskolába gyermeküket, azonban a Kárpátaljai Magyar Pedagógusszövetség adatbázisa alapján tudjuk, hogy a 2008/2009-es tanévtől már nem müködött a településen iskola. Tehát a szülők végül az iskola hiánya miatt kénytelenek voltak más településre vinni gyermeküket, és így a döntési lehetőség következtében mégiscsak az ukrán tannyelvű iskolát választották.

A fenti vizsgálati eredmények alapján elmondható, hogy az etnikailag heterogén családokban a szülök legtöbbször olyan motivációk mentén döntenek a tannyelv kiválasztáskor a többségi nyelv mellett, amely a többségi állam rejtett oktatás- és nyelvpolitikájában a többségi nyelv pozíciójának megerősítését, a kisebbségi nyelv értéktelenségét, leértékelődését szorgalmazza, vetíti elő. Szintén jelentős azon motivációk száma, amelyek a magyar nyelven történő tanulás fontosságát, illetve a nyelvtudás (kisebbségi és/vagy többségi) megszerzését tűzik ki célul. Azonban az etnikailag vegyes házasságok esetében a beiskolázás során nyelvi stratégiaként többségében a többségi nyelv elsajátítását tűzik ki célul, bár több esetben is együtthatóként megjelenik a kisebbségi nyelv elsajátítása, beszédszintű megőrzése.

\section{Felhasznált irodalom}

Bálint Emese (2005): A társadalmi kapcsolatháló és a kódválasztás összefüggései: románmagyar kétnyelvű közösségek példája. Regio 16. 2. sz., 12-28.

Ervin-Tripp, S. \& Mitchell-Kerman, C. (1977, szerk.): Childdiscourse. Academic Press, New York.

Göncz Lajos (2004): A vajdasági magyarok kétnyelvüsége. MTT Könyvtár 8., Szabadka.

Molnár József és Molnár D. István (2005): Kárpátalja népessége és magyarsága a népszámlálási és népmozgalmi adatok tükrében. II. Rákóczi Ferenc Kárpátaljai Magyar Főiskola Matematika és Természettudományi Tanszék, Beregszász.

Radó Péter (1996): Asszimiláció és nyelvválasztás a magyarországi szlovének körében. Regio 7. 1. sz., 142-170.

Réger Zita (1990): Utak a nyelvhez. Akadémia Kiadó, Budapest.

Séra Magdolna (2010): Érvek és ellenérvek az iskolai tannyelvválasztásban (avagy az oktatáspolitikai változások hatása a kárpátaljai magyar közösségre, irányított beszélgetések alapján). In: Fábri István - Kötél Emőke (szerk.): Határhelyzetek III. Önmeghatározási kísérletek: hagyományőrzéstől a nyelvi identitásig. Balassi Intézet Márotn Áron Szakkollégium, Budapest, 161-185.

Sorbán Angella (2000): „Tanuljon románul a gyermek, hogy jobban érvényesülhessen”. Az asszimiláció természetrajzához. Magyar Kisebbség, 6. 3. sz., 167-180.

\footnotetext{
7 Mindenképpen megemlítendő, hogy a gyermekkel a vizsgálatot 2010-ben készítettem, s az iskola már 2008-tól nem müködött. Vagyis a szülök nem voltak tájékozottak arról, hogy a településükön nincs is müködő oktatási intézmény és így mindenképpen más településen lesznek kénytelenek beiskoláztatni gyermeküket.
} 